thought about universities may be required. It may be that the present process of channelling so high a proportion of the nation's intelligence into the universities at the public expense needs reconsideration to ensure that we obtain the full benefit of such expenditure, and that there shall be no disastrous levelling down not merely in standards but also in talent, in enterprise and in vision.

\section{RATS, MICE AND MEN}

\section{Control of Rats and Mice}

Edited by Dennis Chitty and H. N. Southern. Vol. I : Rats. Pp. xxxii $+306+4$ plates. Vol. 2 : Rats. Pp. xvi +307-532+4 plates. Vol. 3 : House Mice. Pp. xiv $+226+8$ plates. (Oxford: Clarendon Press; London: Oxford University Press, 1954.) 105s. the set.

TT has taken a Second World War to provoke a 1 systematic study of those familiar commensals, the common rat and the house mouse. Now, they are being extensively investigated, both as pests and as animals in their own right ; but before 1940 most of what passed for knowledge of rat or mouse biology consisted of myth or moral tale. Control, mostly ineffective, depended on alluringly advertised proprietary baits or contraptions, devised without any basis of critical research. The researches described in the three well-produced volumes under notice were carried out by members of the Oxford University Bureau of Animal Population, from the outbreak of war in 1939 to July 1947. Publication was not allowed during war-time and has been made possible now only by a private donation-a curious reflexion on the arrangements available for the dissemination of valuable knowledge. Much unpublished matter remains, and this is deposited at the Bureau.

Despite the delay, this is an important contribution to our knowledge of the biology of Rattus and Mus, and to the methodology of controlling their onslaughts on our food and our health. The first two volumes deal with work on rats, principally the common brown rat, Rattus norvegicus Berkenhout, but with some material on Rattus rattus $\mathrm{L}$. The topics include the nature of the poisons used against rats; the biology of rats in relation to control methods; special observations on feeding behaviour ; and some operational studies, including an account of experiments on rat control in Palestine and the Sudan. Each section reviews other relevant findings, notably from American work which, too, was stiminulated by war; each has a bibliography. Some of the investigations described are inconclusive, and there are many loose ends; but bringing together such a body of work-an unusual enterprise, and one which might be copied elsewhere on a smailer scale - enables the many biologists and others interested in applied research and its organization to see what is involved in the investigation of three related pest species. On this general point, the introduction by the director of the Bureau, Charles Elton, is particularly worth study.

The procedures recommended for routine control by men with little training are necessarily highly simplified. D. Chitty and others show how laborious was the research which lies behind now familiar techniques such as prebaiting and change of bait and poison, and the actual selection of the poison and its concentration. About one thousand field tests, each usually lasting several weeks, were carried out, and some hundred tests were made on rats in cages. The results are, however, of interest to others besides the rat-catcher, the warehouse-keeper or the medical officer. These volumes contain original data on the closely observed behaviour of feral rats and micedata of a kind which could not have been obtained from experiments on laboratory varieties. In its present form this information is adequately related neither to current ethological field studies nor to the psychology of white rats, and it presents a notable challenge to the student of mammalian behaviour. There is very full information on what the authors call 'new object reaction' in rats -an (innate?) avoidance behaviour or 'neophobia' which clearly has much to do with the success of these animals. There is also information on poison 'shyness' or the refusal of a food which has caused illness-a phenomenon which should stimulate further study of the abilities of rats to select an advantageous diet.

On the ecological side, much has been learnt of rat population dynamics. Part of this work has been separately published; in these volumes the data on the growth and decline of rat numbers in different circumstances are scattered among several chapters, and are mainly related to assessing the effects of attempts at large-scale control. A. D. Middleton, for example, describes operational research on rat control on a grcup of farms - an encouraging instance of what can be done, at reasonable cost, with sound planning; and Elton and Laurie describe a sample census of rats and mice in corn-ricks in England, with results much less encouraging for those concerned with rural rat control.

The study of what actually happens to pest populations when control is attempted, in relation to the amount of damage they cause, is an essential basis for a rational system of control. The Bureau's findings make a useful starting-point for future operational research, but important generalizations on this topic are scattered through various chapters, or made only by implication: there is no point at which the threads of the argument on rat numbers are brought together in a unified statement.

There is greater unity in the third volume, on Mus musculus L., since the final writing was almost wholly the work of the editor, H. N. Southern. It was only with the Second World War that the house mouse was found to be a serious agricultural pest in Britain, but surveys from 1940 on showed it to be abundant on farms and highly destructive in ricks. In grain stores, of course, its activities can be devastating. Its behaviour is markedly different from that of the common rat: while the latter is conservative but 'suspicious', the mouse is mercurial and unpredictable. The Oxford work on this species has produced, for the first time, a sound basis for control by poisoning or trapping, and also a foundation for future studies of mouse biology.

The scientific worker on pest control must often, necessarily, be a jack-of-all-trades, though perhaps not necessarily with the proverbial corollary. Eight years of research by a team of such workers have, as would be expected, produced results of value to biologists working in a number of diverse fields, both 'pure' and applied. It is to be hoped that these volumes will be correspondingly widely used. 